Article

\title{
Pastoral Resilience among the Maasai Pastoralists of Laikipia County, Kenya
}

\author{
Edwin Ambani Ameso ${ }^{1, *}$, Salome Atieno Bukachi ${ }^{1}$, Charles Owuor Olungah ${ }^{1}$, Tobias Haller ${ }^{2}$, \\ Simiyu Wandibba ${ }^{1}$ and Steve Nangendo ${ }^{1}$ \\ 1 Institute of Anthropology, Gender and African Studies, University of Nairobi, P.O. Box 30197-00100, Nairobi, \\ Kenya; sallybukachi@yahoo.com (S.A.B.); owuorolungah@uonbi.ac.ke or \\ owuorolungah@gmail.com (C.O.O.); swandibba@yahoo.com (S.W.); nangendo@yahoo.com (S.N.) \\ 2 Institute of Social Anthropology, Universitat Bern, Lerchenweg 36, 3000 Bern 9, Switzerland; \\ tobias.haller@anthro.unibe.ch \\ * Correspondence: edwin_ameso@yahoo.com; Tel.: +254-726052731
}

Received: 11 May 2018; Accepted: 11 June 2018; Published: 19 June 2018

Abstract: This paper addresses pastoral resilience by drawing out the coping strategies and mechanisms utilized by the Maasai Pastoralists through a food system approach, based on the study findings of an anthropological study of pastoralism as a food system in Laikipia County, Rift Valley, Kenya. The co-existence and interactions of pastoralism as a food system with other types of food systems in Laikipia, such as large-scale horticulture, justified the selection of the study site. This paper is guided by the specific objectives aimed at establishing actors and their roles, and describing the institutional settings and changes that sustain the continued practice of pastoralism. Using a new institutionalism approach, the paper focuses not only on the actors and their roles but also on how internal and external forces regulate access and use of common pool resources (CPRs) resulting in food sustainability within the food system amidst climatic challenges and cyclic humanitarian crises. We argue that this has an impact on the food system that continually defines and redefines the actors' roles and institutional settings and changes (formal and informal rules, regulations, values and norms) that in turn affirm the value of pastoral economies and benefits accrued to a wide range of actors beyond the community and leading to pastoral resilience. Data collected through in-depth interviews amongst pastoral households identified actors and their roles in pastoralism in the household with a total of 50 households being conveniently sampled. Key informant interviews with key stakeholders in the food system described the institutional settings and changes and also identified actors and their roles in pastoralism. Three focus group discussions based on age and gender, established the actors and their roles and described institutional settings and changes to supplement data collected from interviews and unstructured observations aimed at giving a better description of the actors and their roles and also point to observable institutional settings and changes within and outside the community group ranches. The findings reveal that actors in the household, state, non-state, and service providers have developed varied coping strategies and mechanisms that sustain pastoralism. The study also identified institutional settings and changes that promote pastoral resilience, notably, private land ownership patterns, co-management of livestock markets, commercialization of herding, decentralization of livestock services, holistic management of pasture and the water-shed management plans. As a result, increased scholarship and advocacy in regards to the concept of co-management of livestock markets, are recommended as a means of understanding the pastoral resilience that the food system exhibits.

Keywords: pastoral resilience; co-management concept; decentralization; holistic management; water-shed management plan; commercialization of herding; Common Pool Resources (CPRs) 


\section{Introduction}

Globally, pastoralism, as a food system, is practiced in the rangelands that cover $25-45$ per cent of the earth's land surface area with two-thirds of these rangelands found in Asia (36\%) and Africa $(30 \%)$ and being used in common. These rangelands, whether warm or cold, have variable and often harsh climates and are sparsely populated with limited common pool resources (CPRs) especially water and pasturelands (Reid et al. 2014 [1]; Dong et al. 2011 [2]). Pastoral cultures relies heavily on livestock rearing which play a very important role in terms of livelihoods, social capital, and as an insurance against disaster (World Initiative for Sustainable Pastoralism, WISP, 2007:2 [3]). Previously, pastoralism was understood as a stepping-stone in socio-economic evolution between hunter-gatherers and a sedentary agricultural lifestyle. However, it has proved a highly innovative production system and a livelihood that has evolved to adapt to climatic and environmental conditions that limit agricultural expansion and other impacts and stressors (Norwegian Refugee Council, NRC, 2014:10 [4]). Currently, pastoralism continues to survive and remain productive within the rangelands in the midst of environmental stresses such as droughts and floods through various actor roles, institutions and knowledge systems that showcase pastoral resilience (Hesse, 2009 [5]). Mobility among the pastoralists allows for extensive utilization of rangelands as common pool resources through the full use of culture and its attributes (Kaye-Zwiebel and King, 2014 [6]).

In Africa, pastoralism takes up 66 per cent of the continent's lands for pastoral production as it is considered to be the most efficient use of rangelands such as the Arid and Semiarid lands (ASALs) of Kenya (NRC, 2014 [4]; Idris, 2011 [7]). According to Little and McPeak (2014) [8], pastoral resilience as a concept draws special concerns and relevance to pastoralism on two issues: climate change with a particular concern for how to build resilient communities in the face of increasingly extreme weather events and humanitarian crises, especially those that can be traced to the most recent drought-and conflict-induced disasters experienced in the Horn of Africa. The WISP (2007:2) [3] acknowledges that the rangelands in the Horn of Africa support a pastoral economy that is based mainly on the production of milk, meat, blood, hides and skins as well as provision of services such as traction and transportation. In Kenya, the pastoral groups such as the Maasai pastoralists inhabit Arid and Semiarid Lands like Laikipia County which are geographically located in the north, East and South of the country and in total account for 36 per cent of the total population which is around 14 million people (GOK, 2014) [9]. The pastoralists continuously face environmental stresses as they constantly navigate the hot and dry climate of the ASALs in search of pasturelands and water sources (Pavanello, 2009) [10].

In the country, 11 counties are clustered as arid, 19 counties as semi-arid and 6 counties as having pockets of arid and semi-arid climatic conditions (ILRI, 2008) [11]. In addition, it is estimated that over 60 per cent of all livestock in Kenya is found in the ASALs and pastoralism employs 90 per cent of the local populations in the ASALs and accounting for nearly 10 per cent of the Gross Domestic Product (GDP) nationally (GOK, 2008) [12]. Farmer and Mbwika (2012) [13] also acknowledge that the market for meat consumption is not only structured in regards to income with a majority coming from the middle class but also pastoral meat and other livestock products find their way into markets of the two large cities in Kenya due to the high demand of the livestock and its products. Moreover, Kenyan meat supplies from pastoralists have been able to reach the Tanzanian market within the East African region and, internationally, the United Arabs Emirates (UAE) and current trends show that new markets are coming up in Qatar, Oman, Kuwait, Somalia and Egypt. This study therefore was aimed at establishing the actors and their roles in pastoralism and describing the institutional settings and changes of pastoralism as a food system.

\section{Pastoral Resilience among the Maasai Pastoralists of Laikipia County}

In Kenya, the Arid and semi-arid lands (ASALs) constitute about 84 per cent of the total land and are populated by about 20 per cent of the country's population (Idris, 2011 [7]). Bobadoye et al. (2016:120) [14] acknowledges that the ASALs are the most vulnerable regions to climate change and 
other natural hazards in the country with a huge impact on livestock rearing, small-holder agriculture and tourism, which are the most dominant sources of livelihoods in these areas. According to Idris (2011:26) [7] pastoralism is practiced in 75 per cent of the ASALs which are largely populated by nomadic pastoral communities like the Maasai pastoralists of Laikipia County in the rift valley region, who rely primarily on their livestock as a source of livelihood and collectively these regions constitute the most marginalized parts of the country. Ouma et al. (2012:91) [15] add that the root causes of most of the crises facing the pastoralists who inhabit the ASALs, in the recent past, have been occasioned by climate variability and change and as well as natural and man-made related factors which have led to recurrent droughts thus leading to water shortages, conflicts over land access and use, and the disruption of the vegetation cycle in these regions that they occupy with limited common pool resources (CPRs).

Bobadoye et al. (2016) [14] allude to the depletion of CPRs within the ASALs as occasioned by prolonged dry spells, drought events and other hazards have for a long time been the lead to severe economic and food security risks as the hazards make it difficult for pastoral communities such as the Maasai pastoralists to maintain their assets and have timely responses to disasters leading to food sustainability of pastoralism as a food system. Ouma et al. (2012) [15] thus argue that, as a result of these repeated severe droughts, pastoralists continue to endure catastrophic losses of livestock, which is their capital and savings, during the drought events.

However, Idris (2011) [7] illustrates that pastoralists have the ability to successfully assess and manage risks occasioned by the vulnerability that they face in the ASALs from climatic hazards, poverty, conflicts, and diseases that make them shrewd managers of risks and leads to pastoral resilience. Limited literature exists on who the actors are and what roles they play in pastoralism as well as how formal and informal institutions (rules, regulations, norms and values) operating within pastoralism as a food system are continuously in a transition from fit to misfit and back to fit again. This paper therefore seeks to provide more insights and add to existing literature on how pastoral resilience among the Maasai pastoralists of Laikipia County is evidenced by establishing the actors and their roles as well as describing the institutional settings and changes that result in the development of coping strategies and mechanisms resulting in the continued sustenance of the food system. These coping strategies and mechanisms are relied upon by actors in the household levels, the involvement of state, non-state and service providers as actors in pastoralism within the commons and outside the commons, the development and use of organizations and associations as actors as well as the transformation of institutional settings and changes utilized in pastoralism.

\section{Methodology}

\section{Study Site}

This study was conducted in Laikipia County, Rift Valley, Kenya. The county is located in the central part of Kenya and it is roughly demarcated by Mount Kenya to the East and South-east, the Aberdares Range to the south and south-west, eastern rift valley to the west, Karisia Hills to the northwest, Mathews Range to the north, and Buffalo Springs National Reserve and Samburu National reserves to the Northeast (Butynski and De Jong, 2014) [16]. It is also one of the 14 counties in the rift valley region and it is bordered by Samburu county to the north, Isiolo County to the north-east, Meru county to the East, Nyeri County to the south-east, Nyandarua and Nakuru counties to the south-west and Baringo county to the west (GOK, 2013) [17] as shown in Figure 1.

Geographically, the county has five administrative units, namely, Laikipia East, Laikipia North, Laikipia Central, Laikipia West, and Nyahururu sub-counties and it is the 15th largest county in the country by land size covering an area of 9700 square kilometres (GOK, 2014) [18]. In Laikipia County 90 per cent of the land is deemed too dry and thus unfit for cultivation, less than 2 per cent of land is deemed highly viable for agriculture, 65 per cent of land is defined as wildlife habitat while 38 per cent of land is comprised of relatively intact, contiguous, and natural habitat (Butynski and De Jong, 
2014) [16]. In addition, the county also consists of a rangeland plateau with a varying altitude of 1500 to 2611 metres above sea level at Ewaso Nyiro basin in the north and Marmanet forest. In the North the mean annual rainfall is estimated to be $40 \mathrm{~cm}$ while in the south-west it is $120 \mathrm{~cm}(\mathrm{GOK}, 2014)[9,18]$.

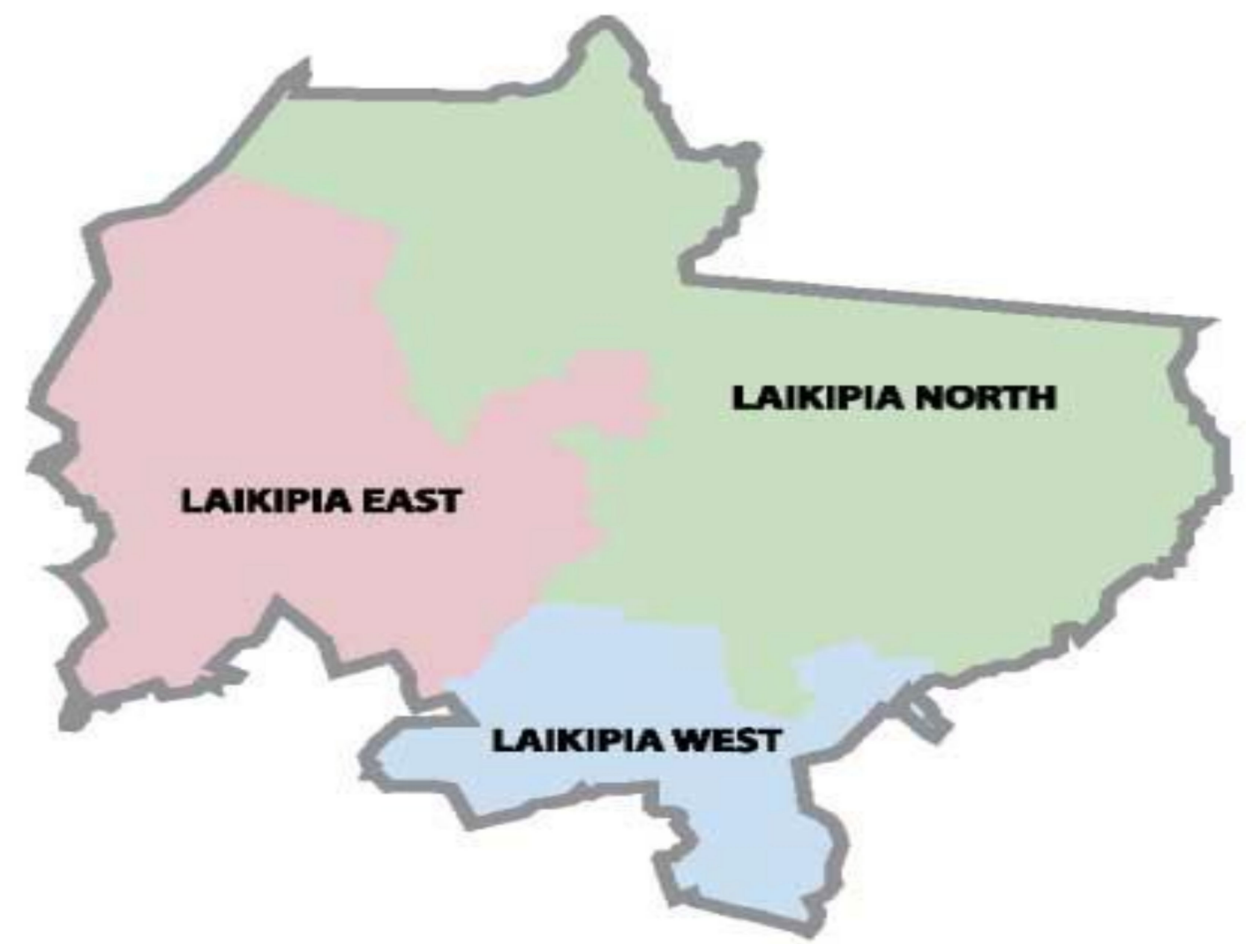

Figure 1. Administrative map of Laikipia County inset the map of Kenya (Source: Munyeki, 2013 [33]).

\section{Methods}

\subsection{Study Population and Sampling Procedure}

The study population consisted of Maasai pastoralists as the Household level actors, state actors, non-state actors, service providers as actors, and organizations and associations as value chain actors in the food system. The unit of analysis was the community that was actively involved in pastoral activities and gained part of their household livelihood through the food system.

The sample consisted of 20 men and 30 women. The proportion of women was higher because they were readily available at the household level. This study collected purely qualitative data and relied on convenient sampling in selecting informants. Secondary data were collected from available literature on the Maasai pastoralists in Laikipia County, actors and their roles, and the institutional settings and changes of pastoralism.

Interviews using in-depth interview guides were conducted with the Maasai pastoralists as actors at the household level. a total of 50 Maasai pastoral households were sampled from within the community group ranches and outside the community group ranches in the vast Segera ward. In total, 25 pastoral households were sampled in Ilpolei group ranches while another 25 Maasai pastoral households were sampled in the vast Segera ward based on the willingness and availability of the pastoral households. This elicited information on the specific objectives establishing actors and their roles in the food system. Other interviews with state, non-state, service providers and organizations and associations as actors were carried out using key informant interview guides to reduce information on establishing the actors and their roles and describing the institutional settings and changes in 
pastoralism. Other data collection methods used included: 3 focus group discussions based on age and gender with men, women and youth were conducted. The discussants were purposively selected from the community households that had not participated in the In-depth interviews. The inclusion of men and women focus group discussions was based on the discussants being 25 years and above and also in a recognized marriage union within the community. Participation for the youth focus group discussion comprised of young men, morans, aged 21-25 years of age. The discussants generated knowledge to address the actors and their roles in the pastoral food system and also alluded to informal and formal institution settings and changes that operate within the food system. Unstructured observations were also used to give insights into the observable institutional settings and changes of the food system and the level of physical interactions teasing out the coping strategies and mechanisms that sustain pastoralism as a food system resulting in food sustainability for the community, region, nation and multinationals at large.

This county's scarce and unreliable rainfall patterns, notably in Laikipia North and Laikipia East sub-counties make it difficult to practice large-scale agriculture (Ameso et al. 2017) [20]. As a result, the two sub-counties are largely pastoral zones where nomadic pastoralism is a major source of livelihood for the inhabitants as shown in Figure 2 [21].

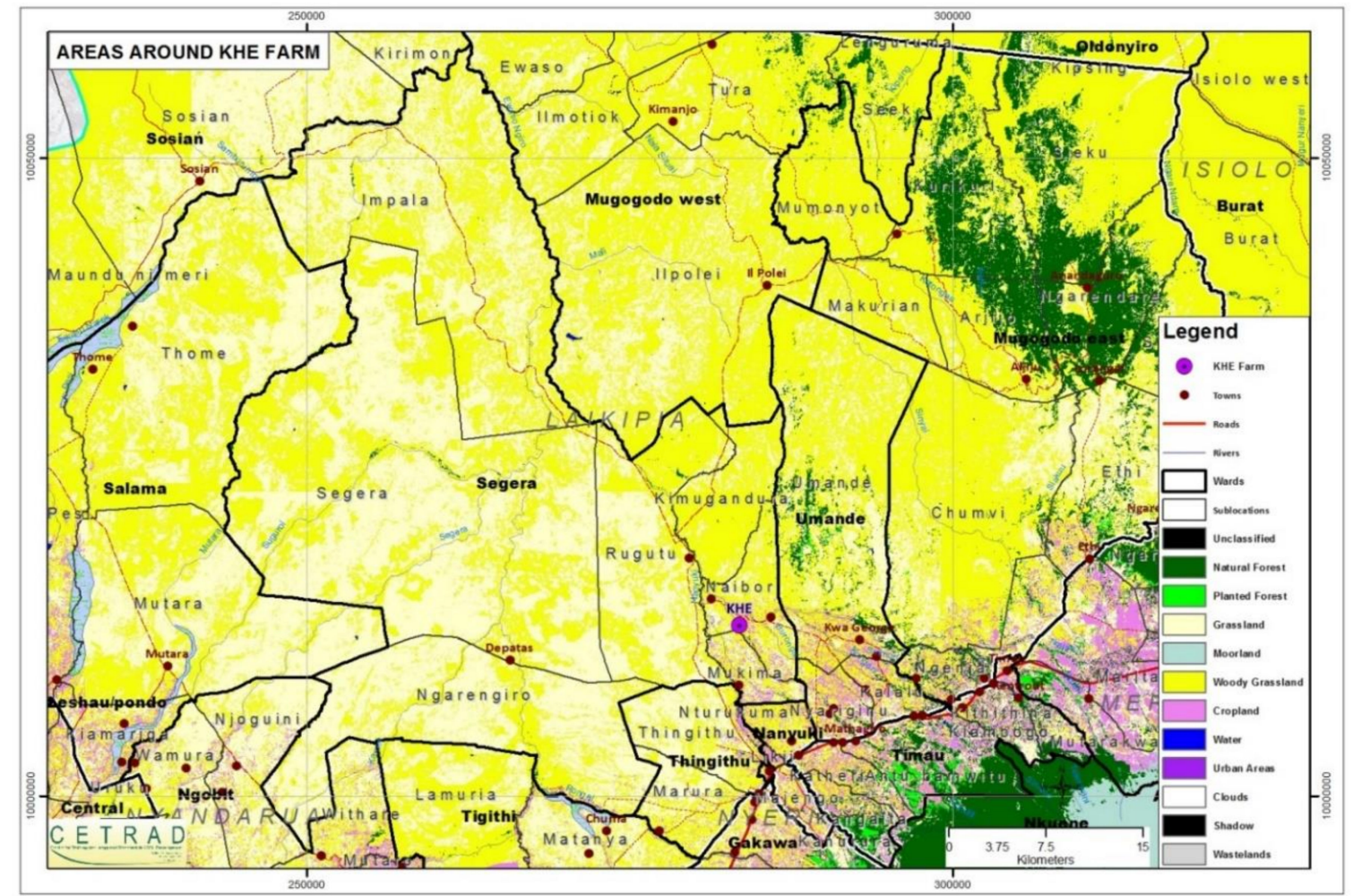

Figure 2. Map of the study area: Laikipia North sub-County.

\subsection{Data Processing and Analysis}

The qualitative data obtained from In-depth interviews, key informant interviews and focus group discussions were recorded, transcribed, and translated into English. Data obtained from unstructured observations and captured in field notes were coded and organized into text for analysis. The two sets of qualitative data were then sorted and interpreted in relation to the research objectives, to provide general interpretations of the findings, indicating how thematic areas and issues interrelated. 


\section{Findings}

Actors and Their Roles in Pastoralism

The household among the Maasai pastoralists is the basic unit of production, distribution, packaging and consumption in the pastoral value chain. It is also responsible for age and gender division of labour in pastoralism to guarantee food sustainability, risk management and resilience. At the household level, various actors have varied roles that they play in pastoralism that guarantee pastoral resilience. Household heads are one such group of actors in pastoralism. They are the men among the Maasai pastoralists who are considered to be the sole owner of the pastoral livestock and the overall-decision makers hence have full control of livestock activities as the main source of livelihood. They are tasked with the overall role of herding livestock thus they have the power to define access to pasture and water for livestock. As the overall decision makers they are capable of delegating their herding role to morans and instructing them on where to graze and water the livestock especially in the commons.

Currently, the study found that the men among the Maasai pastoralists are leaving for town centers in search of formal employment. In order to sustain the continued practice of pastoralism, the men are not only delegating their duties to the morans but also they are hiring herdsmen, fellow Maasai pastoralists with limited education and who remain behind in the commons (community group ranches) and other Maasai settlements outside the commons of Mutirithia, Rumuruti in Laikipia north sub-county. The herdsmen receive a monthly pay of between 5000-7000 Kenyan shillings to herd the household livestock in the absence of the household heads and morans. Moreover, in the 13 community group ranches found in the Maasai reserves, the herdsmen not only receive a monthly pay but also are accommodated with their immediate family members by the hiring pastoral family and become part of the household level actors.

The household heads also manage livestock health through spraying, dipping and injecting of the livestock after they purchase the necessary veterinary medication to combat livestock disease like East Coast Fever (ECF), pneumonia, Anthrax, Foot and Mouth disease (FMD), and Mastitis. It was reported by one household head that:

...We(men) are the ones who are responsible for injecting and dipping the livestock especially the cattle because when it comes to injecting especially the cattle these cows and bulls, it is very hard for women as cows and bulls are strong with tough skin and such livestock is left for the men to treat. This is because men can easily control them since they have the muscles and can subdue the livestock (Male, 31 years, IDI, Ilpolei Group Ranch).

The household heads are also involved in the sale of livestock as they make the final decision on which livestock should be sold and when it should be sold. In the sale of livestock, cultural significance of color is also observed by the household heads. The study was informed that the white and black coloured goats were valued as a source of blessings through the ability of the goats to reproduce quickly and thus regarded as a source of wealth. Moreover, the Irkinyango clan among the Maasai pastoralists of Laikipia values the brown coloured cattle as a source of endless wealth and thus cannot be sold off quickly without having reproduced at least five times.

The study established that selling off such coloured livestock without them having reproduced was equated to inviting poverty into one's household. The men as household heads also decide on when livestock should be slaughtered for household consumption but also allow for continuous extraction of other food components from the livestock, namely, blood and milk. Household heads in special circumstances also perform other roles that are meant to be performed by the women and other pastoral members. For instance, the study was informed that men milk the livestock in the absence of women and the girl-child who are traditionally supposed to milk the livestock twice a day (dawn and dusk). As men grow older and assume the elder's role in the family, at the household level, they still participate in pastoralism by giving constant advice to the morans, men and even herdsmen on the 
appropriate and available pasturelands and watering points to access and use. This however, happens in the community group ranches where these elders understand the geographical stretches of their group lands and to avoid conflict advice their morans, men and herdsmen on the appropriate areas to graze.

Women at the household level coordinate livestock hygiene by cleaning the livestock sheds regularly. They are also tasked with identifying and separating the injured and sick livestock allowing for the nursing of injuries and the treatment of sick livestock. The study was made aware of goats that are separated and treated for partial blindness after the consumption of the invasive and inedible Opuntia plant species. Women also process livestock products such as milk into fermented milk for future consumption. They also process the milk cream through heating and condensation to extract cooking oil. The extracted oil is also used as medicine by the said women who administer it together with special herbs to their children to prevent them against coughs and influenza. The women also preserve meat that is slaughtered at the household level by smoking and drying. The study was informed that the meat can remain preserved and good for consumption for 20-30 days. However, the study found that women currently in other households have taken over household heads roles, especially in families that are single-parent headed households and in households where the man has left for the town centers in search of formal employment. The women hire and pay the herdsmen, purchase veterinary drugs and inject, and spray the livestock.

In the community group ranches, where CPRs are shared communally most men are polygamous and thus have more than one household and several compounds that they call home. In most cases, these men as tradition dictates, with time, move from their first wives households into newly established younger wives households. As a result, the study established that first wives guarantee the continued practice of pastoralism in their households by assuming the household head's roles. They also delegate livestock rearing activities from production, distribution, processing and packaging to their household members based on age and gender. They are also bestowed with the overall decision of whether or not household livestock should be sold and who among the male children will inherit which type of livestock.

Other actors in the household who carry out various roles but lack decision making capacity in livestock rearing that guarantee the continued production, processing, distribution, packaging and consumption of livestock and its products are morans. The morans herd the livestock, provide security to the livestock during the day and night against wild animals and intruders, slaughter livestock meant for household consumption and also administer veterinary drugs to livestock as part of the livestock health management role. As a result of, the commercialization of herding, herdsmen make certain that livestock have access to proper pasture and water. The herdsmen also administer veterinary drugs to household livestock in the absence of the men of the household, help in fencing the livestock sheds and also slaughter household livestock. This was illustrated more by an excerpt from a youth focus group discussion:

Livestock are beneficial as they create employment for men and morans, who are unable to go into towns and get formal employment due to limited education levels. Those who remain behind and have no livestock are being employed as herdsmen by those who have left for town centers, in search of formal employment. More often than not, herdsmen are those men who dropped out of school due to one reason or another. But for those who have finished secondary school education especially for morans, they leave for town centers in search of office jobs. (Youth FGD, Males, Ilpolei Group Ranch).

The young boys who are about 8-10 years of age begin to herd small stocks (calves, lambs and kids) and they also assist their mothers in milking livestock. a male informant from Mutirithia area in Segera ward, when asked about the roles of young boys had this to say:

Young boys who are of age and who have not undergone initiation help in milking the livestock. They also herd the young goats and sheep. Young boys who are old enough as from 8-10 years 
and above graze the livestock. They also help in cleaning the livestock sheds. (Male, 28 years, IDI, Mutirithia).

The study also learnt that young girls mostly complement the woman of the household in dispensing their duties. They separate the small stocks from the larger stocks to allow for milking. They also fetch water and clean the livestock sheds as well as count the livestock as they are brought back from the grazing fields.

\section{Organizations and Associations as Actors in Pastoralism}

The study was informed of organizations and associations that were directly and indirectly involved within and outside the community group ranches in encouraging the practice of pastoralism. The study was informed of Livestock Marketing Authorities (LMAs), which emphasized on the adoption of a core co-management concept of livestock markets. This concept allowed for increased participation of pastoralists in livestock marketing and management of the markets' infrastructure in the pastoral counties of Isiolo, Samburu, and Laikipia. In the County of Laikipia, the Laikipia Livestock Marketing Authority (LLMA), a community-led organization was found that liaises with the County government of Laikipia to collect livestock sales tax and encourages equitable distribution of the said tax during market days in the ratio of 1:1. The organization through its branch leadership which includes a chairman, supervisor, and other senior members of the community selected to serve in the organization's leadership, is found in every available livestock market in Laikipia County acts as the custodian of the sales tax left to the community.

The LLMA leadership in its wisdom retains the revenue allocation left in its possession and later ploughs it back into agreed upon and prioritized community projects that have received public acceptability. For instance, the study established that in Kimanjo market the LLMA had agreed to plough back the revenue allocation into bee keeping projects, hay production projects, building of slaughterhouses in the market, rehabilitation of run-down cattle dips, building market stalls, educating the pastoralists on the adoption of new drought resistant breeds of livestock and rehabilitation of the roads leading to the livestock market in Kimanjo. An officer of the authority echoed these sentiments:

The fifty per cent that is collected as tax during market days and left to the community through the authority is used differently; ten per cent is used to pay salaries of clerks and other authority employees. Twenty per cent is left with the authority as savings while the remaining twenty per cent is used on community initiated projects such as giving bursaries to school going children in the community like here in Kimanjo, investing in bee keeping activities, hay production projects, and building of slaughterhouses. Out of the same amount some is used in improving the community's infrastructure to allow for access to trade areas like available livestock markets. (Male, 37 years, KII, Kimanjo).

Community ranch management groups are another set of actors that encourage the practice of pastoralism in the commons. They are associations founded by members of the available 13 community group ranches found in Laikipia North sub-county of: Ilpolei, Kijabe, Lekuruki, Makurian, Ilgwesi, Morupusi, Kurikuri, Munichoi, Musul, Tiamut, Koija, Ilmotiok and Nkilorit. The community group ranches were registered in the late 1970s such as Ilpolei community group ranch that was registered in 1976. The role of the community ranch management groups is to regulate the use of available common pool resources especially pasture and water through advocating for the adoption and utilization of the concept of holistic management of grazing lands locally referred to as the Olopoleli concept.

The Olopoleli concept gains mandate and implementation support through the community group ranch constitution that zones the communal lands into grazing, settlement and conservation zones. The concept stipulates that grazing land zones should be divided into various parts and some of these parts should be set aside for future grazing during the dry seasons and in the wet seasons the grazing lands that had previously been in use should be enclosed and set aside to allow grass to grow.

The community ranch management groups also take up the lead role in providing alternatives to limited CPRs. The study was informed that the management groups like that of Ilpolei community 
group ranch led by the chairman, are authorized to make agreements with private ranches such as Oljogi during the dry seasons to allow for pastoral livestock to graze in the private ranches that have access to permanent river waters and constant pasture availability. This is done at a fee of 200 shillings per cow or bull after a grazing zone within the private ranches has been identified and terms such as the provision of three herdsmen from the community group ranch to herd the livestock have been agreed upon. The agreements struck for access to pasture and water also allow pastoral livestock to gain access to constant vaccination drives, livestock health management plans and also pay the herdsmen a monthly fee of 7000-8000 Kenyan shillings that will be done at the expense of the private ranch owners.

Livestock trade which is the back of the pastoral economy in Laikipia County has found support from pastoral initiated credit associations. These community-led financial institutions, notably, Nasaruni rural Sacco provides money transfer services and loans to actors who frequent the livestock markets. Nasaruni rural Sacco an initiative of pastoral women in Kijabe community group ranch began in 2008 as a financial service organization for pastoral women but by 2013 it had grown into a fully fledged Sacco. In its current position as a Sacco it provides financial services to the Maasai pastoralists in Laikipia County, as well as to other pastoral groups found in the neighbouring counties of Isiolo and Samburu. The financial institution offers development, educational and emergency loans to pastoralists with livestock being used as collateral. The Sacco takes a picture of the said livestock as evidence of the available collateral before disbursing the loans.

The pastoralists are also required to be part of one of two groups; one comprising of 5-8 pastoralists who can guarantee one another as good neighbours, Kikundi cha Mkopo (KCM) and another a collection of at least $3 \mathrm{KCMs}$ with a membership of close to 30 pastoralists who live in the same village and know one another well enough. The development loans are issued to pastoralists who would like to build permanent housings with iron-sheet roofings and move away from the grass-thatched housings. The educational loans are issued mostly in the month of January to cater for tuition fees of pastoral children, when livestock trade is low and the prices of livestock are unfavorable. In instances, where urgent medical care and other unforeseen circumstances occur, the Sacco issues emergency loans. Laikipia Permaculture Centre (LPC) is another organization as an actor in pastoralism that the study found to be advocating for holistic management of pastoral lands and strict observation of the carrying capacity of the rangelands.

\subsection{State Actors in Pastoralism}

The continued practice of pastoralism in Laikipia County as a food system is also pegged on to the involvement of national and county government actors who: regulate, process, distribute, provide services and add to the number of users and beneficiaries of pastoral trade and products. Police officers are national government employees found in the pastoral regions and mandated with providing security to pastoral actors especially in livestock markets. Their sole responsibility is to guarantee free and fair trade for livestock buyers and sellers. Through the County Market officials, the county government of Laikipia is represented in the pastoral economy. They are employees of the county government, previously of the municipal council of Laikipia. They are charged with the sole responsibility of collecting sales tax in livestock markets from livestock buyers and sellers.

The study was informed that they collect 30 Kenyan shillings from livestock buyers and sellers per sheep and per goat, and they also collect 200 Kenyan shillings per cattle bought or sold. They also sit down with the Laikipia Livestock Marketing Authority management and share the sales tax collected and make certain that the half that is meant for the county government of Laikipia is safely secured and taken to the County coffers. The County market officials are aided by Livestock counting clerks in sales tax collection in livestock markets. The livestock counting clerks are employees of the LLMA.

Veterinary officers are also employees of the county government who provide livestock health management to the food system. They conduct regular vaccination drives in the event of notifiable livestock diseases, train the pastoralists on proper purchase and use of veterinary drugs and impose 
possible quarantines. They operate in pastoral regions and the slaughterhouses within the county where they make certain that the livestock brought for slaughter by actors in pastoralism meet the necessary requirements before they are slaughtered and released to the public for county and national level of consumption.

In livestock health management, the veterinary officers conduct livestock disease surveillance in the pastoral regions along two main stock routes and within the livestock markets where buying and selling of pastoral livestock takes place. In Laikipia north sub-county, the study was informed that the two main stock routes were those used by the Maasai pastoralists in search of water and pasture for their livestock during the dry seasons. The first stock route moved from Kirimon to Kimanjo then to Ilpolei in the pastoral commons into Kimkandura and Endana and finally reaching Mount Kenya or the Arbedare ranges. The second stock route began in Kirimon and moved to Rumuruti outside the pastoral commons and from there into Nyahururu sub-county of Laikipia before ending up in the much greener Arbedare ranges.

Livestock production officers of the county government of Laikipia train pastoralists on proper animal husbandry methods and ensure that the carrying capacity of the rangelands is observed. They also advise the pastoralists on which drought resistant breeds to keep, and the better veterinary drugs to use. When it comes to the livestock trade among food system actors, the livestock production officers advise the pastoralists on the need to form Livestock Marketing Authorities (LMAs) to ensure they get better prices for their livestock. They also work with the Maasai pastoralists on rangeland management to ensure they deal with the menace of receding rangelands caused by the invasive plant species of Opuntia.

Another national actor is the Agricultural Sector Development Support Programme (ASDSP). They work with the Maasai pastoralists to ensure that their products value chains are created with their input. They also advice the Maasai pastoralists on how to increase the market value of their livestock and livestock products through the use of quality inputs in livestock rearing like dewormers. They also discourage the pastoralists from having an overreliance on purchasing inputs from stockists and other open air market vendors of veterinary drugs with poor storage. They also talk with the pastoralists on formation of marketing associations like LLMA and promote electronic marketing of livestock and their products as a measure of guaranteeing a better market value for the sale of pastoral livestock and products.

\subsection{Non-State Actors in Pastoralism}

Non-governmental organizations within and outside the pastoral commons of Laikipia county regulate and provide services to pastoralism that encourage its growth. Regenesis limited and African Wildlife foundation (AWF) are two non-state actors who work with the Maasai pastoralists to strengthen their financial position by helping the pastoralists save money from their pastoral activities. The two organizations have worked with the pastoral women of Kijabe community group ranch and led to the growth of Nasaruni rural Sacco from a financial service organization in 2008 to a full-fledged Sacco in 2013.

The Regional Pastoral Livelihood Resilience Project (RPLRP) is a World Bank funded resilience project hosted by the department of Livestock production in the County government of Laikipia that works to eliminate the invasive plant genus of Opuntia. The study was informed that the project was initiated in late 2015 and began full operations in 2016 with an aim of establishing the hazards that pastoralism in 14 arid and semi-arid counties such as Laikipia, Isiolo, Turkana, Samburu and Wajir face. The project uses the Community Managed Disaster Risk Reduction Assessment (CMDRRA) to get Maasai pastoralists to identify the hazards that they face. The study was informed that CMDRRA listed Opuntia invasive plant genus as one of the main hazards that limits pastoralism and needs to be dealt with.

The African Conservation Centre (ACC) is another actor in pastoralism that encourages the practice of livestock rearing and trade. It focuses on livelihood projects aimed at improving the 
livestock breeds that the Maasai pastoralists keep in Laikipia and Narok Counties as well as Amboseli and Maasai Mara conservancies. In Laikipia County and predominantly in the Maasai reserves, the organization is working towards improving availability of pasture by emphasizing on the adoption of the Olopoleli concept. Moreover, the organization is on the forefront, working with women groups such as Twala women group to build gabions to reduce soil erosions in the commons and encourage the retention of water through the water-shed management plan.

\subsection{Service Providers as Actors in Pastoralism}

Agro-vets are one type of service providers who contribute to the health of the pastoral livestock by providing ready veterinary drugs to Maasai pastoralists within and outside the commons. They are found in livestock markets of Doldol, Kimanjo, and Naibor with stalls in which they operate in. Others are peripatetic and they frequent the county of Laikipia from neighbouring counties of Nyeri and Meru to sell off their veterinary drugs during market days.

Food merchants such as local butchers, hoteliers, and milk vendors provide a ready market for pastoral products, namely, milk and meat. They sell the products in their raw form to residents of the town centers found within the pastoral regions and also as ready-to-consume products to frequent actors in livestock markets who make stopovers in the town centers of Juakali and Naibor outside the pastoral commons and in Ilpolei town centre in the pastoral commons.

Livestock brokers are another group of actors whose goal in pastoralism is purely profit-maximization. These young pastoral men and women are actively involved in livestock trade by purchasing livestock from fellow pastoralists at a lower price and rearing the livestock for awhile before reselling them at a higher price in livestock markets, to butchers within the town centres or butchers at the slaughterhouses such as Nanyuki Slaughterhouse in Laikipia County and, Huruma and Dagoretti slaughterhouses in Nairobi City county.

Livestock buyers are business persons who frequent the livestock markets in Laikipia County to purchase pastoral livestock. These livestock buyers are non-pastoralists who come from as far as Nyeri, Murang'a, Meru and Nairobi counties. They purchase livestock from the Maasai pastoralists in livestock markets with profit-maximization as a motivational factor. They process and package the livestock products through slaughterhouses and distribute the meat and other livestock products to their customer base in butcheries, supermarkets, food outlets, hotels, and security, health and education institutions with which they have pre-existing business agreements. Some of the products have specific markets based on the concentration of consumers. The study was informed of Eastleigh, South B and South C as designated markets for camel meat consumption inhabited by residents of the Somali ethnic group in Nairobi City County. Livestock buyers work hand-in-hand with livestock transporters who provide transport services to the former. They ferry the purchased livestock from the pastoral regions to desired designations like Endana and Nanyuki town in Laikipia County as well as to Nyeri, Murang'a and Nairobi City Counties and towns like Karatina.

\section{Institutional Settings and Changes as Coping Strategies and Mechanisms in Pastoralism}

Changes in formal and informal rules, regulations and norms governing the practice of pastoralism have enhanced pastoral resilience in Laikipia County among the Maasai pastoralists within and outside the pastoral commons. Changes in actor roles have been experienced amongst household level actors to varying degrees but institutional transformations have emerged as coping strategies and mechanisms ensuring the continued practice of pastoralism. The study was informed of changes in primary actor roles. The study found that household heads left their primary role of herding livestock in pastoralism as they opted to leave for town centres in search of formal employment while education for the morans changed their primary role in herding livestock. However, in order to cope with these changes in primary actor roles that threaten the survival of pastoralism, institutional changes within the Maasai pastoralists have allowed for the outsourcing of herding roles to herdsmen at the household level for a monthly fee. Other leadership household head roles' have also been delegated to women who have 
taken control as livestock owners and authority figures. In Maasai pastoral households that cannot afford the services of herdsmen, women have also taken up the role of herding as well as livestock health management.

Coping strategies and mechanisms by the Maasai pastoralists have also been witnessed in regards to pasture. The pastoral regions occupied by the Maasai have over the years been vulnerable to prolonged drought spells and other hazards such as the outgrowth of the invasive Opuntia plant species in the commons. To bounce back, from limited pasture supply in the commons, the Maasai pastoralists are relying on set down formal and informal rules and regulations established in their community group ranch constitutions. The constitutions have zoned pastoral lands into grazing, settlement, and conservation zones and this guarantees preservation of given pasture lands for future use through the emphasis on the use of and adoption of holistic management of pasturelands. Moreover, to ensure that the enshrined rules and regulations are followed, the community group ranch management and elders have sanctions and punishments in place for offenders. The study found that for first time offenders who take their livestock into the restricted and reserved pasturelands for grazing they are given a warning but for second time offenders they are forced to part away with a he-goat as a fine for grazing in restricted zones and reserved pasturelands. For third time and repeat offenders legal actions which involves notifying the local administration is taken and a jail term is a possible outcome.

In the pastoral commons, the Maasai pastoralists also hire pasture fields from neighbouring private ranches like Oljogi, Impala, Olgarama, Olpajeta, Lenaisho and Oldega. Other Maasai pastoralists are re-investing the money from livestock trade into private land ownership outside the commons to guarantee continued access to pasture for their livestock in areas like Mutirithia in Segera ward.

Outside the commons, the Maasai pastoralists cope with limited pasture constrains by purchasing more than one plot in areas such as Mutirithia in Segera ward. They fence the plots and utilize one after the other on a rotational basis for grazing. In other areas such as Karionga in Segera ward, the pastoralists hire grazing plots available from non-pastoralists at a monthly fee of between 7000-8000 Kenyan shillings. Other pastoralists sneak their livestock into neighbouring privately owned ranches to graze as a coping strategy and mechanism. The large livestock is sneaked into privately owned ranches at night while the small stocks are sneaked into these ranches during the day. This is done to avoid the small stocks from being predated upon by the wildlife found in private ranches.

Water shortage is also another hindrance to the practice of pastoralism. To cope with water shortage, the Maasai pastoralists in the commons who rely on seasonal rivers like Twala River make informal agreements with private ranches through their group ranch chairmen for their livestock to have access to water when they are grazing in the private ranches. Another strategy is the dependence on dams constructed through private-public partnerships between private ranch owners and county and national government departments. The study found that Oljogi private ranch had partnered with the Ministry of Irrigation and built a dam for the Ilpolei community group ranch. Other partnerships between the community group ranch management and conservation based non-governmental organizations such as the African Conservation Centre, has allowed for the building of gabions to reduce soil erosion within the community group ranches through the water-shed management plan.

Outside the commons, the Maasai pastoralists rely on water dams to meet the water needs for their livestock in areas such as Mutirithia. In other regions of Segera ward such as Karionga, pastoralists rely on boreholes dug by their agricultural neighbours and they purchase water at a fee of 50 Kenyan shillings per $20 \mathrm{~L}$ jerican. However, other pastoralists rely on the permanent water supply of river Nanyuki to meet their livestock water demands.

With devolution, pastoralism has stood out as a very important revenue generator for the county government of Laikipia. As a result, the sales tax collected in livestock markets has increased from 20 Kenyan shillings per goat or sheep to between 30 or 40 Kenyan shillings per goat or sheep. The sales tax collected per cattle sold has also increased from 100 Kenyan shillings before the dispensation of the county government and its involvement to 200 Kenyan shillings per cattle. The increased revenue 
collection has been attributed to the co-management policy and concept that has been picked up in the management of livestock markets.

With the dispensation of County governance in Laikipia there has been a sharp increase in the cost of livestock vaccinations from 70 Kenyan shillings to 150 Kenyan shillings and the responsibility of livestock health management has been relegated to individual Maasai pastoralists. However, despite all this setbacks in livestock health management, pastoralists are developing organizations and associations such as Laikipia Livestock Marketing Authority that are geared towards providing quality inputs through providing readily available veterinary medications for pastoral livestock through building of veterinary drug stalls that are operated by qualified veterinary officers.

\section{Discussion of Findings}

\subsection{Actors and Their Roles in Pastoralism}

The study identified actors along the value chain (production, processing, packaging, distribution and consumption) in the household, state, non-state and service providers in the food system. This is concurrent with, Young et al. (2012) [22], who regard pastoralism as a livestock production system that encompasses numerous extensive interests across sectors, disciplines, states and non-state groups. The actors identified were found to play different but complementary roles along the value chain within the food system. This is similar to Ferraro and Andreatta (2012) [23], who acknowledge that pastoralism sustains a wide-range of actors through the raising of domestic animals and also uses them for transportation and trade. Similar sentiments are echoed by Young et al. (2012) [22], who posit that pastoral livestock production makes a significant contribution to securing the livelihoods of actors within and beyond the food system.

Bonvillain (2013) [24] posits that, among the pastoralists, at the household level, rules regulating gender roles exist allowing for access to livestock products. For example, the study established that milking is a woman's role and for young girls who are above 10 years of age. Additionally, within the Maasai community a strict division of labour that is organized on age group and gender roles ascribed to by all members exist. As a result, primary producers in the food system were identified as heads of households (men), women, morans, elders, young boys and girls, and herdsmen who were found mainly at the household level. Similarly, Bee et al. (2002) [25] agree that men in the Maasai community are heads of the household, owners of livestock and traditionally responsible for security and provision of medical care to the livestock. Additionally, Blench (2001) [26] adds that men herd and sell meat animals within the food system. Kituyi (1990) [27] also points out that in line with tradition, the responsibility of slaughtering in the household is always retained by the household head, who has the overall responsibility of deciding who or what to be slaughtered and in most cases he delegates the roles of slaughtering to a moran. However, the study established that in addition to the morans being delegated the slaughtering role; the same role can also be delegated to herdsmen by the household head or by the women at the household level, who are in-charge of their households. This is in line with FAO (2017) [28], which acknowledges that pastoralism relies on a list of strategies at the household level to address labour shortages such as the joining with other households in cooperative herding and watering, taking in impoverished dependants or borrowing a child usually from close kin, expansion of the household through marriage and more recently the hiring of labour for herding, herdsmen.

For women in the household, they are not only responsible for milking but also herding the small stocks and young livestock while at home, cleaning the livestock sheds and also processing milk through fermentation process and also extracting cooking oil from the milk cream. This is in line with Morner (2006) [29], who acknowledges that women in pastoral communities are normally assigned the right to milk, conduct dairy processing and beyond that they may or may not sell milk but usually have control over the proceeds. Additionally, Ferraro and Andreatta (2012) [23] posit that oil extracts from milk among the pastoralists can be used to prepare vegetables that the pastoralists get from exchanges with non-pastoral actors. 
The morans are tasked with herding, slaughtering selected livestock for household consumption, health management of livestock and provision of security by the household heads. Similar findings are shared by Morner (2006) [29], who states that morans in the Maasai community, search for new pasture for their livestock, defend and protect their livestock from wild animals and rival tribes and support their parents in pastoralism generally. Additionally, Bee et al. (2002) [25] add that morans grant security for the community and educate the young ones on matters related to animal husbandry, resource use, and good comportments and more crucially, they move with livestock in search of pasture and water.

In the household, the young boys begin to learn livestock responsibilities through introduction at a tender age. They are introduced to herding of calves, kids, and lambs near their homes but as they get older, 10 years of age and above, they begin to herd the larger livestock. According to Hauff (2003) [30] young boys only herd livestock by strictly adhering to grazing schemes given to them by elders and household heads. Similarly, Tarayia (2004) [31] acknowledges that at an early age, the young boys, herd calves, lambs and kids close to their home compounds. According to Morner (2006) [31] when boys are about 5 years of age, their fathers take the responsibility of teaching them on how to take care of their livestock herds and by the time they are 10 years of age and above, the boys are tasked with the main responsibilities of larger livestock.

For organizations and associations as actors, they are involved in reinforcing community participation in pastoral activities like in livestock markets as well as in developmental projects like rehabilitation of cattle dips. As a result, employment and credit access among the food system actors has increased remarkably and more returns from livestock rearing trickles down to the primary actors. Bee et al. (2002) [25] concurs that such involvements with organizations and associations not only maintain the position of pastoralism as a major source of subsistence, at the household and community level, but also act a major income creator for the community at large.

Service providers as actors, most notably, food vendors trade in livestock products, also provide livestock inputs like veterinary drugs to control livestock diseases and manage total livestock health. Others engage in the constant trade of pastoral livestock such as butchers, hoteliers and livestock brokers. According to Lengoiboni et al. (2011) [32] livestock provides pastoralists not only provide sustenance at the household level but also through constant exchange of livestock products and livestock sales, and the food system provides a means of financing basic needs.

\subsection{Institutional Settings and Changes in Pastoralism}

The management of CPRs especially pastures and water in the food system is governed by actors with differing bargaining powers and positions through formal and informal institutions, namely, rules, regulations, values and norms. With time, changes in roles of some primary actors such as household heads have changed due to education and the desire for formal employment. The resultant effect has been women assuming temporal powers and positions of household heads who have left for town centers in search of formal employment. Moreover, women have also been bestowed the power to hire and pay herdsmen to take up roles left behind by morans as the community embraces formal education. According to Kaye-Zwiebel and King (2014) [6] institutions dictate the utilization of extensive rangelands and the uptake of food system activities as they are an outcome of customary polycentric governance systems and social networks that allow not only for the proper management of CPRs but also the responsibilities of individuals. Similarly, Tarayia (2004) [31] highlights that among the Maasai, for generations, they have had customs regulating occupation of land that is strictly governed by natural laws that give out the rights to control and use CPRs. Haller (2013) [33] adds that followers and kinsmen make certain that they monitor the pastures and water access and use. Sanctions are then issued to those who access the CPRs without gaining proper user rights.

\section{Conclusions}

In summary, the study established that there are different actors found along the value chain with varying decision making capabilities and bargaining powers in the food system. At the household 
level, the men are the ultimate decision makers and are also the sole owners of the livestock who decide on the use of livestock and their products, and the access to and use of CPRs. Women have limited decision making capabilities while the morans, young boys and girls, and herdsmen lack decision making capabilities.

Additionally, changing actor roles' is a current phenomenon in the food system, with household heads and morans who are leaving for urban areas in search of formal employment and education, respectively. Women are now taking up the roles previously reserved and performed by the household heads and morans, by hiring herdsmen for the latter and assuming decision making capabilities of the former.

The study has also established that actor roles' are being defined and redefined by formal and informal institutions (rules, values, norms and regulations). As a result, the study found that value-chain actors, in the household, state, non-state, and service providers as actors as well as co-management policy and water-shed management plans are vital in regulating and providing services for the food system.

\section{Recommendations for Further Studies}

From the study, with regards to actor roles, value chain actors with different bargaining powers and varying roles exist within the food system, in the household, community and beyond. In the household, actors' roles are defined and redefined by formal and informal rules, regulations, values and norms operating within the food system as producers, processors, packers, distributors and as consumers. Therefore, there is a need for broader studies targeting larger sets of the study population, to elaborate on the food system actors', their roles and effects of institutional settings and changes.

Secondly, alterations in the formal and informal management of CPRs like pasture, water and land necessitate changes in rules, regulations, values and norms governing access and use of resources within a devolved system of governance. The emergence and restructuring of various actors and their roles to fit within the new constitutional dispensation and power structures and still remain relevant and sustain the persistent utilization of pastoralism as a food system thus need to be examined further.

For policy concepts like co-management, water-shed management plan, and holistic management of pasturelands as well as decentralization of livestock services need to be further examined to understand how such informal and formal rules, regulations, values and norms interact and merge into highly adaptive and coping mechanisms that contribute immensely to pastoral resilience. Additionally, advocacy for the adoption of such policies by other larger sets as a way of promoting pastoral resilience within the food system is highly recommended.

Further studies should be conducted with some public-private partnerships like the Regional Pastoral Livelihood Resilience project, a project of the World Bank working in collaboration with national and county governments to eradicate the Opuntia invasive plant species in pastoral regions and as a result, promoting pastoral resilience. Moreover, the community centered approaches like the CMDRRA used in search of an initiative emphasizes the need to examine pastoral resilience from a people centered approach, hence amplifying the position of pastoralism as a domestic food system.

Author Contributions: Identified the research site, recruited the informants, collected and analyzed data, E.A.A. Initial conceptualization of the study topic to data collection and editing and reviewing of the manuscript, S.A.B. Proposal writing stage to data collection and editing and reviewing of the manuscript and administrative support, C.O.O. Reviewed and edited the thesis and reviewed the manuscript, S.W. and S.N. Read, edited and reviewed the manuscript, T.H.

Funding: The research received fieldwork facilitation from the Sustainable Governance of Food systems (R4D) project through the Center for Training and Integrated Research in Arid and Semi-Arid Lands (CETRAD).

Acknowledgments: My deepest appreciation and gratitude is extended to the Twala women group for their accommodation during my data collection period, to the Rana family especially; Peter Rana, Thomas Rana and Joseph Rana who tirelessly assisted me in data collection and all my informants and discussants who participated in providing information. I also acknowledge the County and National state actors notably; Livestock production officers, livestock health officers, county slaughterhouse management and the Agriculture Sector Development Support Programme, Laikipia County especially; Mr. Martin Kamau Mutuga and Mrs. Peris Nyakio Mutua 
for participating in the study. Furthermore, many thanks go to organizations and associations notably Laikipia Livestock Marketing authority and Laikipia Permaculture centre for allowing me access to interview them.

Conflicts of Interest: The authors declare no competing interest.

\section{References}

1. Reid, S.R.; Fernandez-Gimenez, M.E.; Galvin, K.A. Dynamics and Resilience of Rangelands and Pastoral peoples around the globe. Annu. Rev. Environ. Resour. 2014, 39, 217-242. [CrossRef]

2. Dong, S.; Wen, L.; Liu, S.; Zhang, X.; Lassoie, P.J.; Yi, S.; Li, X.; Li, J.; Li, Y. Vulnerability of worldwide pastoralism to global changes and interdisciplinary strategies for sustainable pastoralism. Ecol. Soc. 2011, 16, 10. [CrossRef]

3. WISP. Pastoralists as Shrewd Managers of Risk and Resilience in the Horn of Africa; WISP Policy Brief No. 4; IUCN Eastern Africa Regional Office: Nairobi, Kenya, 2007.

4. Norwegian Refugee Council (NRC). On the Margin: Kenya's Pastoralists: From Displacement to Solutions: a conceptual Study on the Internal Displacement of Pastoralists; Internal Displacement Monitoring Centre: Geneva, Switzerland, 2014.

5. Hesse, C. Generating wealth from environmental variability: The economics of pastoralism in East Africa's drylands. Pastor. Indig. Aff. 2009, 3-4, 14-21.

6. Kaye-Zwiebel, E.; King, E. Kenyan pastoralist societies in transition: Varying perceptions of the value of ecosystem services. Ecol. Soc. 2014, 19, 17-37. [CrossRef]

7. Idris, A. Taking the camel through the eye of a needle: Enhancing pastoral resilience through education policy in Kenya. Resil. Interdiscip. Perspect. Sci. Humanit. 2011, 2, 25-38.

8. Little, D.P.; McPeak, J.G. Pastoralism and resilience south of the Sahara: Building resilience for food and nutrition security. In Proceedings of the 2020 Conference Brief 9, Addis Ababa, Ethiopia, 15-17 May 2014.

9. GOK. The 2014 Long Rains Season Assessment Report: Kenya Food Security Steering Group, KFSSG; Government Printers: Nairobi, Kenya, 2014.

10. Pavanello, S. Pastoralists' Vulnerability in the Horn of Africa: Exploring Political Marginalization, Donors' Policies and Cross-Border Issues_Literature Review; Humanitarian Policy Group Report; ODI: London, UK, 2009.

11. International Livestock Research Institute (ILRI). Livestock Market Access and Opportunities in Turkana Kenya; Research Report 3; ILRI: Nairobi, Kenya, 2008.

12. GOK. Sessional Paper No. 2 of 2008 on National Livestock Policy; Government Printers: Nairobi, Kenya, 2008.

13. Farmer, E.; Mbwika, J. End Market Analysis of Kenyan Livestock and Meat: a Desk Study; USAID Micro Report No. 184; USAID: Nairobi, Kenya, 2012.

14. Bobadoye, A.O.; Ogara, W.O.; Ouma, G.O.; Onono, J.O. Assessing climate change adaptation strategies among rural Maasai pastoralists in Kenya. Am. J. Rural Dev. 2016, 4, 120-128.

15. Ouma, C.; Obando, J.; Koech, M. Post drought recovery strategies among the Turkana pastoralists in Northern Kenya. Sch. J. Biotechnol. 2012, 1, 90-100.

16. Butynski, M.T.; De Jong, Y. Primate Conservation in the rangeland agro-ecosystem of Laikipia County, Central Kenya. Primate Conserv. 2014, 28, 117-128. [CrossRef]

17. GOK. Laikipia County: First County Development Integrated Development Plan, 2013-2017; Government Press: Nairobi, Kenya, 2013.

18. GOK. County Assembly of Laikipia: Strategic Plan, 2013-2018; Draft 3; Government Printers: Nairobi, Kenya, 2014; Volume 1.

19. Munyeki, J. The Standard Media Group: Kiunjiru, Muriithi engage Uhuru in popularity contest-Map of Laikipia County. Available online: https://www.standardmedia.co.ke/article/2000074568/kiunjurimuriithi-engage-uhuru-in-popularity-contest-in-laikipia (accessed on 15 June 2018).

20. Ameso, E.A.; Bukachi, S.A.; Olungah, C.O.; Haller, T. Ethnography of the slaughterhouse: a case of Nanyuki slaughterhouse in Laikipia County, Rift Valley, Kenya. Pastoralism 2017, 7, 32. [CrossRef]

21. CETRAD. Map of Laikipia North Sub-County: Showing the Study Areas of Mukogodo East, Mukogodo West and Segera Wards; CETRAD: Nanyuki, Kenya, 2017.

22. Young, H.; Rahim, A.; Mohammed, A.; Fitzpatrick, M. Pastoralism and Pastoralists in Sudan: a Stakeholder Mapping and Survey; Short Report; Feinstein International Center, Tufts University: Medford, MA, USA, 2012. 
23. Ferraro, G.; Andreatta, S. Cultural Anthropology: An Applied Perspective, 9th ed.; Wadsworth: Belmont, CA, USA, 2012.

24. Bonvillain, N. Cultural Anthropology, 3rd ed.; Pearson Publishing: Boston, MA, USA, 2013.

25. Bee, K.F.; Diyamett, M.L.N.; Towo, E.N. Challenges to Traditional Livelihoods and Newly Emerging Employment Patterns of Pastoralists in Tanzania; International Labour Organization: Geneva, Switzerland, 2002.

26. Blench, R. 'You Can't Go Home Again': Pastoralism in the New Millennium; Overseas Development Institute: London, UK, 2001.

27. Kituyi, M. Becoming Kenyans: Socio-Economic Transformation of the Pastoral Maasai; African Centre for Technology Studies Press: Nairobi, Kenya, 1990.

28. Food and Agriculture Organization (FAO). Labour and Livestock Management. 2017. Available online: http:/ / www.fao.org/wairdocs/ilri/x5552ex5552e08.htm (accessed on 30 May 2018).

29. Morner, S. The Maasai: Changes in Livelihood after Land Loss. Bachelor's Thesis, Sodertorn University College Press, Sodertorn, Swedish, 2006.

30. Hauff, E.L. The Effects of Development on the Maasai. Bachelor's Thesis, St. John's University, New York, NY, USA, 2003.

31. Tarayia, N.G. The legal perspective of the Maasai culture, customs and traditions. J. Intern. Comp. Law 2004, $21,184$.

32. Lengoiboni, M.; Van der Molen, P.; Bregt, K.A. Pastoralism within land administration: Seasonal interactions and access agreements between pastoralists and non-pastoralists: a case of northern Kenya. J. Arid Environ. 2011, 75, 477-486. [CrossRef]

33. Haller, T. The Contested Floodplains: Institutional Change of the Commons in the Kafue Flats, Zambia; Lexington Books: Lanham, MD, USA, 2013.

(C) 2018 by the authors. Licensee MDPI, Basel, Switzerland. This article is an open access article distributed under the terms and conditions of the Creative Commons Attribution (CC BY) license (http:/ / creativecommons.org/licenses/by/4.0/). 